\title{
Upholding the integrity of your CMAJ
}

\author{
Diane Kelsall MD MEd, Kirsten Patrick MB BCh DA, Matthew B. Stanbrook MD PhD, Barbara Sibbald BJ, \\ Ken Flegel MD, Erin Russell MSc, Dorian Deshauer MD, Jayna M. Holroyd-Leduc MD, Monika Kastner PhD, \\ Sharon Straus MD MSc, George Wells PhD, Moneeza Walji MD MPH
}

$\mathrm{O}$ n Feb. 29, 2016, the Canadian Medical Association (CMA) disbanded the CMAJ's Journal Oversight Committee (JOC), dismissed Editor-in-Chief Dr. John Fletcher and set up a task force to consult on the future vision and governance of the journal. ${ }^{1}$ It is not up to us to explain the CMA's decisions. However, CMAJ's editors wish to thank Dr. Fletcher for his loyal stewardship of the journal and to assure stakeholders of our ongoing commitment to ensuring that $C M A J$ remains a world-class journal of integrity and quality.

$C M A J$ has been Canada's leading medical journal for more than 100 years, through 19 editors-in-chief. It has changed its look, format and governance structure many times. Some transitions have been rocky, but the journal's reputation has endured. We can boast of publishing numerous award-winning editorials and news articles, practicechanging research and guidelines, and expert analysis that has influenced practice and policy. The signatories of this editorial are choosing to stay on to help preserve this legacy.

We are profoundly disappointed that, although the CMA recognizes the value of $C M A J$, both as an important member service and as an influential voice in the global medical publishing arena, it chose to denigrate the performance of the journal in its press release on Feb. 29. ${ }^{1}$ A falling impact factor and decline in research submissions were offered as reasons. Although it had dipped in the past, CMAJ's impact factor is on the rise.

Under Dr. Fletcher's leadership, the journal has raised its profile substantially. In the past four years, the CMAJ team expanded $C M A J$ 's presence on social media; launched a thriving open access journal, CMAJ Open, as a service to Canadian and international researchers; developed podcasts and blogs to contribute to debate on important topics; and met with researchers across Canada and internationally as part of our program of editorial outreach. We continue to publish influential research papers and other articles that affect health policy and clinical practice.

Despite what you may have read in the popular media over the past week that drew parallels with events in $2006,{ }^{2}$ there has been no explicit breach of editorial independence on this occasion. However, the dismissal of Dr. Fletcher and the disbanding of the JOC - the body that arbitrated between $C M A J$ and the CMA Board - are distressing to us. The recommendations of the CMAJ Governance Review
Panel final report ("the Pound report") — which strengthened the JOC - were explicitly designed in 2006 to protect editorial independence. ${ }^{3}$

We have been assured by the CMA and the CEO of NewCo, the CMA subsidiary to which CMAJ was transferred in late 2014, that the "CMA Board of Directors will continue to fulfill its existing role of ensuring complete editorial independence for $C M A J^{\prime \prime}$ and that the editor-in-chief will have unimpeded access to the CMA Board on matters of editorial independence. Some have understandably questioned the credibility of such an assurance when, as of this writing, CMA has offered no plausible public justification for the dismissal of the Journal Oversight Committee and the effective shredding of the Pound report. ${ }^{3}$ We remain firmly united in the position that a failure to uphold our editorial independence would be intolerable.

The stated aim of the new CMAJ task force, which will be led by Dr. Chris Simpson, CMA past-president, is to "consult with members and propose recommendations for a new mission statement, goals and objectives for $C M A J^{\prime \prime} ;{ }^{1}$ importantly, it will also look at governance. Interim Editor-in-Chief Dr. Diane Kelsall and Deputy Editor Dr. Kirsten Patrick will sit on the four-member task force, along with Ann Michael, president of the Society for Scholarly Publishing and a NewCo Board member.

As the current editorial custodians of $C M A J$, we ask that you - members of the CMA, physicians of Canada, and our Canadian and international authors, readers and reviewers engage with the task force and make your views known. What sort of journal would you feel proud to call your journal? What type of publication would honour the 105-year legacy of $C M A J$ but continue to be relevant and useful for new generations of physicians? How do you want to access and interact with the journal? How do you want its legacy safeguarded?

Rest assured that CMAJ is conducting business as usual. We thank authors and reviewers for their continued contributions to the journal. However, $C M A J$ 's editors are all too well aware that editorial independence reaches beyond the control of what we publish; it can be influenced by budgetary and organizational constraints. Our aim in participating in the task force is to make sure that $C M A J$ 's editorial integrity is carefully safeguarded.

We are proud to be a part of CMAJ. We hope that you will continue to support and be proud of it, too. 


\section{EDITORIAL}

\section{References}

1. CMA Board of Directors announces restructuring and modernization plan for CMAJ. Ottawa: Canadian Medical Association; 2016. Available: https://www.cma.ca/En/ Pages/cma-board-of-directors-announces-restructuring-and-modernization-plan-for-the -cma-journal.aspx

2. Weeks C. Critics decry Canadian medical journal's 'Orwellian' revamp. Globe and Mail [Toronto] 2016; Feb. 29.

3. CMAJ Governance Review Panel final report. Ottawa: Canadian Medical Association; 2006. Available: www.cmaj.ca/site/pdfs/GovernanceReviewPanel.pdf

Competing interests: See www.cmaj.ca/site/misc/cmaj_staff.xhtml

Affiliations: Editor-in-Chief (interim) (Kelsall), Deputy Editor (Patrick, Stanbrook), News and Humanities Editor (Sibbald), Senior Editor (Flegel), Assistant Editor (Russell), Associate Editor (Deshauer, Holroyd-Leduc, Kastner, Straus, Walji), Biostatistical Consultant (Wells), CMAJ

Correspondence to: CMAJ editor, pubs@cmaj.ca

CMAJ 2016. DOI:10.1503/cmaj.160283 